University of Wyoming College of Law

Law Archive of Wyoming Scholarship

\title{
Thinking in Circles: Using OODA to Sharpen Legal Analysis
}

Kenneth D. Chestek

University of Wyoming College of Law, kchestek@uwyo.edu

Follow this and additional works at: https://scholarship.law.uwyo.edu/faculty_articles

\section{Recommended Citation}

Chestek, Kenneth D., "Thinking in Circles: Using OODA to Sharpen Legal Analysis" (2020). Faculty Articles. 41.

https://scholarship.law.uwyo.edu/faculty_articles/41

This Article is brought to you for free and open access by the UW College of Law Faculty Scholarship at Law Archive of Wyoming Scholarship. It has been accepted for inclusion in Faculty Articles by an authorized administrator of Law Archive of Wyoming Scholarship. 


\title{
Thinking in circles: Using OODA to sharpen legal analysis
}

\author{
Kenneth D. Chestek ${ }^{1}$
}

Jan. 15, 2009. Three minutes after takeoff from LaGuardia airport, US Airways Flight 1549, with 155 people on board, was climbing routinely, approaching 3,000 feet of altitude. Suddenly the pilot, Capt. Chesley Sullenberger, saw something up ahead.

"Birds!" he cried out.

One second later, Sullenberger heard the sound of thumps and thuds on the windsheild and fuselage of the Airbus A320 he was piloting. That sound was followed immediately by sounds that no pilot, crew member, or passenger ever wants to hear: the sound of both engines "chewing themselves up inside, as the rapidly spinning, finely balanced machinery was being ruined, with broken blades coming loose." The smell of burning birds was being sucked inside of the aircraft. Sullenberger and his co-pilot, Jeff Skiles, "felt a sudden, complete, and bilaterally symmetrical loss of thrust."2

Within eight seconds of the bird strike, Sullenberger realized that "this was the worst aviation challenge l'd ever faced. It was the most sickening, pit-of-yourstomach, falling-through-the-floor feeling I had ever experienced." He knew he had to take control of the situation.

"My aircraft," Sullenberger told his co-pilot.

"Your aircraft," the co-pilot responded. ${ }^{3}$

$1 \quad$ Professor of Law and Director of Externships, University of Wyoming College of Law. This article is based upon a presentation by the author at the $19^{\text {th }}$ Annual Rocky Mountain Legal Writing Conference in March, 2019 at the William S. Boyd School of Law at the University of Las Vegas. The author wishes to thank the members of the Rocky Mountain Legal Writing Scholarship Group, especially Nantiya Ruan, Amy Griffin, Jennifer Cooper, Derek KiernanJohnson, Todd Stafford, Robert Anderson and Maikieta Brantley, who provided helpful feedback on an initial draft of this article. Ruth Anne Robbins and Melissa Weresh also provided valuable insight into early drafts. Finally, many thanks to Todd Jagger of Wolf-PAC for showing me the power of OODA as an analytical tool.

2 Chesley Sullenberger, Highest Duty: My SEARCh For What REALly MatTers (Wm. Morrow 2009), at 206-209.

Id. at 210 . 
The story of US Airways Flight 1549 that midwinter day in 2009 is familiar to all of us. Capt. Sullenberger, an Air Force fighter pilot and flight instructor who went on to piloting commercial aircraft for nearly 30 years, ${ }^{4}$ was able to take control of the frightening situation that had come upon him so suddenly. He managed to safely land his aircraft in the Hudson River, where ferry boats were able to spontaneously respond and safely evacuate all 155 passengers and crew. ${ }^{5}$ The incident has come to be known as "the Miracle on the Hudson."

Since Capt. Sullenberger was trained at the Air Force Academy as a fighter pilot, it is likely he was trained in the OODA method of problem-solving (Observe, Orient, Decide, Act). ${ }^{6}$ While the OODA process likely helped Capt. Sullenberger save 155 lives that day, it also turns out that OODA is a useful paradigm for solving almost any sort of problem, from the mundane to the life-threatening.

Lawyers are nothing if not problem-solvers; the well-being of their clients depends upon good problem-solving skills. This article proposes OODA as a way of thinking systematically about any legal problem, and hopefully working through the problem in a comprehensive and systematic way to get to the best result for the client.

Part I of this article discusses the origins of the OODA principle, including how OODA works and what can cause it to fail (i.e., when it leads to a poor decision). It also shows how OODA can be employed not only to lead a decisionmaker to a good decision, but how it can be weaponized to lead an opponent into a bad decision. Part II then briefly discusses how OODA works in a legal setting, both from a global perspective (using the example of the evolution of the common law) but also in the context of individual cases. It describes how a poor OODA process can lead courts to make poor decisions.

$4 \quad$ See generally, id.

$5 \quad I d$. The incident was turned into a major motion picture, Sully, starring Tom Hanks in the role of Capt. Sullenberger. (How to cite a movie? Warner Bros. 2016).

6 In his autobiography, Capt. Sullenberger does not identify OODA specifically as his thought process. Instead, he said he fell back on his military training: when confronted with an aircraft emergency, (1) maintain aircraft control, (2) analyze the situation and take proper action, and (3) land as soon as conditions permit. Sullenberger, supra n. 2, at 212-213. But that second step—analyze the situation and take proper action—can perhaps be most easily understood as an OODA process. 
Parts III and IV get more specific. Part III discusses how OODA can help a lawyer think through a case to provide complete advice to her client. Part IV focuses on how OODA might help a legal writer present an argument to a tribunal. Finally, Part V considers the ethical implications of OODA. While OODA in its original military context is a very useful way of defeating an enemy, in a legal context very different rules apply.

This article is primarily a thought experiment. There is a developing body of scholarship on creative problem-solving in legal contexts. In 1992, the MacCrate Report identified problem-solving as a "fundamental lawyering skill." It defined problem-solving as "Identifying and Diagnosing the Problem," "Generating Alternative Solutions and Strategies," "Developing a Plan of Action," "Implementing the Plan," and "Keeping the Planning Process Open to New Information and New Ideas." "Since then, scholars from clinical, skills and legal writing disciplines have described what "problem solving" looks like from a lawyer's perspective. ${ }^{8}$

Lawyers, and law professors in particular, are not the only custodians of wisdom and understanding. From time to time it behooves us to look outside of our own discipline to see if we can learn something from others. I'm not sure yet where OODA can lead us; but it seems to me there is important insight to be had from studying and understanding the concept. My intent here is to add to the discussion of lawyers as problem solvers by proposing this new tool as a potentially helpful way of structuring a lawyer's thought process in seeking optimal solutions for her

7 SECtion on Legal Educ. \& Admissions to the Bar, AmericAn Bar Assoc., Legal EdUCATION AND PROFEsSional DEVELOPMENT-AN EDUCATIONAL CONTINUUM (REPORT OF THE TASK ForCE ON LAW SchoOLs AND THE PROFESSION: NARROWING THE GAP 138 (1992). These steps bear a strong resemblance to the OODA process.

8 See, e.g., Larry O. Natt Gantt, II, the Pedagogy of Problem Solving: Applying Cognitive Science to Teaching Legal Problem Solving, 45 Creighton L.Rev. 699 (2012); Carolyn Grose, Uncovering and Deconstructing the Binary: Teaching (And Learning) Critical Reflection in Clinic and Beyond, 22 Clinical L. Rev. 301, 308 (2016); Katherine R. Kruse, Biting off What They Can Chew: Strategies for Involving Students in Problem-solving Beyond Individual Client Representation, 8 Clinical L. Rev. 405 (2002); Stefan Krieger, Domain Knowledge and the Teaching of Creative Legal Problem Solving, 11 Clinical L. Rev. 149 (2004); Linda Morton, Teaching Creative Problem Solving: A Paradigmatic Approach, 34 Cal . Western L. Rev. 375, 382-83 (1998); Kurt M. Saunders \& Linda Levine, Learning to Think Like a Lawyer, 29 U. San Francisco L. Rev. 121, 140 (1994); Katheen Elliott Vinson, What's Your Problem?, 44 Stetson L. Rev. 777 (2015). 
clients.

\section{The Origins of OODA}

Col. John Boyd was a fighter pilot for the United States Air Force. ${ }^{9}$ More significantly, however, he was also a deep thinker about military strategy and decision-making in life-or-death situations. In that context, he discovered that good decisions depend upon a good OODA process.

OODA stands for:

Observe (detect the problem to be solved)

Orient (gather relevant data needed to solve the problem)

Decide (process the data, leading to a conclusion)

Act (implement the answer which results from the Decide process)

This formulation is similar to the analytical frameworks proposed by several

See generally RoBert CORAM, Boyd: THE FIgHTER PILOT WHO CHANGED THE ART OF WAR (2002). Coram describes Col. Boyd as "one of the most important unknown men of his time. . . . But much of what he did, or the impact of what he did, was either highly classified or of primary concern to the military." Id. at 7. The beauty of OODA, however, is that it describes virtually every decision-making process, and therefore can be applied to virtually any situation. Id. at 334 .

This is not the first law review article to discuss the OODA loop. See, e.g., Thompson Chengeta, Defining the Emerging Notion of "Meaningful Human Control" in Weapon Systems, 49 N.Y.U. J. Int'l L. \& Pol. 833 (2017) (discussing the relative roles of humans and machines in the OODA cycle) Brandon Garrett, A Tactical Fourth Amendment, 103 Va. L. Rev. 211 (2017) (discussing the OODA loop in the context of police tactics); Alan L. Schuller, At the Crossroads of Control: The Intersection of Artificial Intelligence in Autonomous Weapon Systems With International Humanitarian Law, 8 Harv. Nat'l Sec. J. 379 (2017) (discussing problems when some phase of the OODA process is given to machines); Jeffrey L. Vagle, Tightening the OODA Loop: Police Militarization, Race, and Algorithmic Surveillance, 22 Mich. J. Race \& L. 101 (2016) (discussing OODA in the context of military automated surveillance systems and techniques by civilian police departments). One practitioner has also written a book explaining in some detail how OODA can help a trial lawyer make quick decisions in the crucible of a trial. A.S. Dreier, STRATEgy, PlanNing \& Litigating To Win: Orchestrating Trial Outcomes with Systems Theory, Psychology, Military Science AND UTILITY THEORY (Conatus Press 2012). This article is, however, one of the first articles to extends the OODA principle beyond the law of war or military- or police-related decision processes, or to legal analysis more generally than in a trial setting. 
clinical education scholars. Some of those frameworks seem to stop at the "act" phase, ${ }^{10}$ while others take the next step and re-evaluate the new situation in light of the chosen action. ${ }^{11}$ But all of these processes seem to deal only with the front end of the client representation: evaluation of alternative solutions and selection of strategies. The OODA loop is scalable: it can help a lawyer choose from among alternative strategies at the outset of the representation, but can also help guide

For example, clinician Carolyn Grose describes as "Client Rounds," a process which "contain[s] four distinct phases: fact gathering, diagnosis, problem-solving, and evaluation." Grose, supra n. 3, at 308 (2016).

Professors Kurt M. Saunders and Linda Levine also described a similar process:

The objective of problem solving is to make the implicit explicit: given a problem, the task is to construct a path to its solution. Problem solving begins when a person recognizes that a problem exists and then forms a representation of the problem by understanding the nature of the gap to be crossed. Next, he or she plans a solution by choosing a path or strategy for crossing the gap, and then implements that strategy. Finally, he or she evaluates the solution as to how effectively it solves the problem, and thereby learns from the experience of solving the problem. The success of problem solving depends on how effectively a person carries out these processes.

Saunders \& Levine, supra n. 3, at 140 (1994). The end of the cycle described by Saunders and Levine, however, is only student learning; like Prof. Grose's "client rounds" method, it does not require re-evaluation of any new problems created by the proposed solution.

Prof. Linda Morton has also proposed a similar six-phase process for problem solving, the sixth step of which does require re-evaluation:

Does our solution solve the problem? (If not, the problem may need further analysis, or alternative solutions. In other words, we must return to some phase on the wheel.) Are we better off than before? What other problems might the solution create? Can any of those additional problems be prevented now? If so, how and by whom? If not, should we still implement the solution chosen?

Morton, supra n. 3, at 382-83 (1998). Likewise, Prof. Kruse includes re-evaluation as her final step:

Although people divide and name the stages of problem-solving differently, all provide the same basic sequence of steps or phases to describe the process of problem-solving, which can be generalized into four basic stages: (1) identifying the problem; (2) exploring alternative solutions; (3) developing and implementing a strategy for solving the problem; and (4) revising and modifying the strategy in light of new information.

Kruse, supra n. 3, at 422-23. 
subsequent decision as the case develops and unexpected things happen.

\section{A. How OODA works}

This process works for any sort of decision, from the mundane to the life-ordeath problems ${ }^{12}$. Let us start with the life-or-death example that Col. Boyd was probably thinking about when he came up with the OODA process:

You are a fighter pilot on a routine sortie. Suddenly, your radar detects an unidentified object rapidly approaching you from behind. If the object is a friendly plane, you are okay. But if it is hostile (a plane or a missile), you are in very grave danger. Here's how your OODA process would work:

Observe: There is an unidentified object rapidly closing on me from behind.

Orient: Where am I in the sky? Over what territory am I flying? Have enemy fighters been flying in this space? Are there hostile ground forces with SAMs in the area? Has there been any communication from the approaching object? At what rate and by what vector is the object closing? Is it an airplane or a missile? What countermeasures do I have available to distract or confuse the other pilot, or the missile? What evasive measures are available to me? Are there friendly aircraft flying near me to give me assistance? And probably hundreds of other things that you have been trained to think about and evaluate.

Decide: Friend or foe? If foe, evade or distract? Or both?

Then you Act on whatever you decide.

For this situation, obviously, the OODA process must be extremely fast; in fact, the faster you run through the process, the greater your chances of surviving. ${ }^{13}$ But also note that the process depends not only on fast thinking, but good Orientation. You must gather complete and accurate information, as quickly as

12 This discussion is an oversimplification of what was, for Col. Boyd, a highly complex and nuanced process. For an excellent, if bewildering, chart of the process, see Coram, supra n. 4, at 344 .

$13 \quad$ For military applications, speed in processing OODA is of the essence. "The military believes speeed is the most important element of the cycle, that whoever can go through the cycle the fastest will prevail." Id. at 334-35. Obviously, in the calm of a lawyer's office, speed is usually not of as much concern. 
possible, so that the correct decision can be made. Your life literally depends on it.

Let us return to Capt. Sullenberger and the Miracle on the Hudson incident described at the beginning of this article. His OODA process may have gone something like this:

$\begin{array}{ll}\text { Observe: } & \text { We've hit birds and lost thrust in both engines. } \\ \text { Orient: } & \text { What is working? } \\ & \text { Electrical still good } \\ & \text { Hydraulics still good } \\ & \text { Conclusion: I'm piloting a glider. }\end{array}$

The key to understanding OODA analysis is that it is constantly adjusting to changed circumstances. The situation that a problem solver finds himself in is constantly changing; an effective OODA analysis takes that fact into consideration, and allows the problem-solver to adjust to rapidly changing circumstances, even if those circumstances change before you get to the Decide and Act steps. Capt. Sullenberger's conclusion in the first loop of his OODA process forced him to change tactics quickly:

Observe: I'm piloting a glider.

Orient: $\quad$ I am flying at just under $300 \mathrm{MPH}$

I'm at 3,000 feet altitude

The plane is descending at a rate of 1,000 feet per minute I have less than three minutes of unpowered flight left I need to buy more time in the air to make it back to the airport

Decide: I need to lower the plane's nose to achieve the best glide speed.

Act: $\quad$ Adjust the flaps and lower the plane's nose.

Every Act taken at the end of an OODA process changes the world in some way, large or small. The actor must then re-Observe the changed world: has the problem been solved? If not, then what? Or has the Action created a new problem? 
Capt. Sullenberger needed another iteration of OODA:

Observe: My rate of descent has slowed. What airport is now in range?

Orient: $\quad$ LaGuardia is behind me and to my left

Newark a little farther out to my right

Teterboro closer to my right but much shorter runway

Hudson River is under me

ATC is clearing runways at LaGuardia and Newark to let me land

At current rate of descent I can't make any of those airports.

Decide: I need to ditch in Hudson. The plane will be lost but maybe we can save some lives.

Act: $\quad$ Lands plane in Hudson River. ${ }^{14}$

Col. Boyd, who first described the OODA process, recognized that it the process is so iterative that he called it an "OODA loop." Let's examine the looping by returning to the fighter pilot example. Suppose the pilot in our example concludes (correctly) after his initial OODA process that it is a hostile missile chasing him. Suppose further that the Action he chooses is to deploy chaff to confuse the incoming missile's radar guidance system. Having deployed the chaff, the pilot makes a new Observation, starting the next iteration of the OODA loop. Did deploying chaff solve his problem?

Observe: The missile flew right through the chaff, and is still following me.

Orient: The chaff did not distract the missile's guidance system. Therefore the missile must be a heat-seeker rather than radar-guided, and it is following my engine. I need to get it to seek a different heat signature. I have other counter-measures to deploy against heat-seeking missiles.

Although he does not explicitly describe this thought process in terms of OODA, these are the steps Capt. Sullenberger described in his autobiography of how he made the decision to ditch the plane in the Hudson River. Sullenberger, supra at n. 2, at 215-239 
Decide: I will attempt to confuse the missile by deploying flares, then radically throttle back so my engine cools quickly and the missile then follows one of the hot flares.

Act: I deploy the flares, radically throttle back and immediately change direction.

Upon taking this Action, the pilot must now evaluate the changed circumstances and engage in yet another loop of the OODA process:

Observe: The missile followed a flare, and is no longer chasing me. Problem solved.

Observe: The missile is still chasing me.

Orient: What other countermeasures do I have available?

....and on and on until the problem is solved.

\section{B. How OODA can fail}

Note that a successful OODA process depends on both the Observe and Orient phases being complete and accurate. For example, in his first iteration of OODA Capt. Sullenberger was able to correctly Orient himself to determine that his plane had lost all engine power and was unlikely to ever regain it. Had he failed to understand that the bird strike had destroyed both of his engines, he might have spent too much time trying to restart his engines, and lost the ability to safely land the plane in the river. ${ }^{15}$

\section{The dark side of OODA}

OODA, conceived as a military strategy, has a dark side. Boyd took OODA a step further and described how one could attack an enemy by intentionally disrupting the enemy's OODA processes, thereby leading the enemy to an

15 Capt. Sullenberger engaged in what Prof. Grose might call "critical reflection ... the process of asking questions before seeking answers, and then evaluating what we have learned, and what more we need to know before moving forward." Grose, supra n. 3, at 315. 
inaccurate or fatal decision and action. ${ }^{16}$ Two ways to disrupt the enemy's OODA process is to lead him to fail to detect your presence or your intentions (hiding to prevent Observation) or to provide false inputs to his Orientation process (deception or sowing confusion so that the enemy's decisions do not respond to the real threat). ${ }^{17}$

Let's return briefly to the example of a heat-seeking missile closing in on our fighter pilot. The pilot is executing his own OODA processes to respond to the threat, but the missile (as an automated agent of the hostile force) is working OODA too:

Observe: I have been assigned to chase down that airplane and blow it up.

Orient: I have detected a heat signature from the plane's engine. It has just veered to the left.

Decide: I must veer to the left to follow it.

Act: I change my flaps to change course and follow it.

And each time the plane changes course to evade the missile, a new OODA process allows the missile to make compensating course corrections and stay on target.

The only way for the pilot to shake this missile, then, is to disrupt the missile's OODA process. He does so by deploying hot flares, firing off in different directions, while simultaneously spinning down his own engine to reduce its heat signature. The missile's OODA look then looks like this:

Observe: There are many heat signatures suddenly diverging from the one l've

Generating a rapidly changing environment-that is, engaging in activity that is so quick it is disorienting and appears uncertain or ambiguous to the enemy-inhibits the adversary's ability to adapt and causes confusion and disorder that, in turn, causes an adversary to overreact or underreact.

Coram, supra n. 4, at 328. Coram goes on to say that "[t]he key thing to understand ... [is] the need to execute the cycle in such fasion as to get inside the mind and the decision cycle of the adversary. This means the adversary is dealing with outdated or irrelevant information and thus becomes confused and disoriented and can't function." Id. at 335.

17 This is actually the theory behind every terrorist attack: disrupt your enemy's normal Observation and Orientation processes in hope that it will respond disproportionately or irrationally. $C f$. YUVAL NOAH HARARI, 21 LESSONS FOR THE $21^{\text {ST }}$ CENTURY (2018), at 166-68. 
been following.

Orient: Which one is the plane's engine? They are all very hot. One of them might be the afterburners as the plane tries to outrun me.

Decide: The hottest signature is probably the plane's afterburner. I will follow it.

Act: I change my flaps to change course and follow the hottest heat signature. And since the pilot suddenly reduced the engine's heat signature by throttling back, the missile flies off course and tries to kill a flare.

The pilot saved himself by disrupting the OODA process of the incoming missile. By deploying countermeasures, he interfered with the missile's ability to Observe and Orient to the new condition, leading it to make a bad Decision. ${ }^{18}$

All of these principles have direct application in thinking about legal reasoning and the formation of litigation strategy.

\section{OODA and the law}

Lawyers are problem-solvers, too. Every legal problem requires a series of OODA processes to resolve them. A judge Observes: the defendant has filed a 12(b)(6) motion to dismiss the case, and I must decide it. She Orients herself: she reads the Complaint; reads the Motion to Dismiss; reads the briefs filed by the parties; does her own research to fill in any gaps or to check the veracity of the claims made by the parties; and other activities. She then processes all of that information to Decide: motion denied. She Acts by writing an order and opinion explaining her decision.

And that act affects the lawsuit by allowing it to go forward. It creates a series of new problems to be solved: the parties will now engage in discovery, which could lead to more disputes for the court to decide. There could be a Motion for

18 While disrupting the enemy's OODA process might make good military strategy, I am not advocating that a lawyer try this. It is not a good idea to hide the real issue from the court or the jury, or seek to confuse it. And using such tactics against opposing counsel might result in an uncomfortable meeting with the attorney disciplinary authorities of your jurisdiction. However, as we shall see in section [x] below, disrupting an opponent's OODA process might be something an advocate is tempted to do. 
Summary Judgment after discovery is complete; there could be Motions in Limine or other motions to decide before trial. There could be a trial. Every stage of the proceeding will require another OODA process, and the decision in each step will affect future behavior of the parties or create new problems to be solved. ${ }^{19}$

It isn't just lawsuits that use an OODA loop process. The law itself develops via an endless OODA loop; this is how the common law grows. Appellate Court A must decide an appeal. It Observes the issue or issues presented. It Orients itself by reading the record, reading the briefs of the parties, conducting its own research. It Decides the case by applying the rules it has discovered during the orientation phase; critically, the rule of stare decisis guides the court to decide this case consistently with precedent cases. It then Acts by issuing an opinion and order.

And we now come to the crux of the problem: the decision of Appellate Court A changes the world by becoming part of the body of law that Appellate Court B must take account of when the next case presenting the same or similar issues arrives. Appellate Court B uses a new OODA process to decide that case, which then itself changes the world by becoming part of the body of law that Appellate Court C must take account of. This is how the common law (or interpretations of Constitutional or statutory law) grows and changes incrementally.

But if Appellate Courts B, C and beyond do not adequately Observe the new problems created by the Act of the previous court, then the new OODA cycle goes off course, and each new Decision and Act compound the undetected problem of the preceding courts. By this I mean that courts need to Observe not just the way the law has changed after the previous decisions, but how the world (i.e. society at large) has changed as a result of the previous decisions. A court needs to consider: did the previous decision(s) solve a problem, or just create new problems to be solved $?^{20}$

As I have argued elsewhere, a failure by a court to completely and objectively

19 Of course, a decision to grant the motion affects the world in a different way and sets off a series of alternative decisions by the plaintiff: do I replead? Do I appeal? Do I walk away? And OODA restarts from this new condition.

20 I have argued elsewhere that a series of defective OODA loops has led the United States Supreme Court to an erroneous ruling in Citizens United v. FEC, 558 U.S. 210 (2010). See 
Observe the new condition created by its decision can lead to surprising results. ${ }^{21}$ Take the example of the much-maligned decision in Citizens United v. FEC ${ }^{22}$, which endowed corporations with the right of political speech in direct advocacy for political candidates. The development of this surprising result began innocently enough when the Supreme Court recognized that corporations possessed some rights possessed by natural humans, like the ownership of property ${ }^{23}$ in order to allow them to serve the functions for which they were created. Then, through a long series of decisions spanning more than 200 years, corporations gradually gained more and more rights, small increment by small increment, leading to the Citizens United case which expressly grants corporations the right of political speech. ${ }^{24}$ No court along that chain seemed to notice the inexorable accumulation of political power in already-powerful institutions, and how that power has diminished the voices of average human beings.

To some extent, this short-sightedness is baked into the doctrine of stare decisis. Under this doctrine, courts are supposed to decide each new case consistently with previous cases, deciding no more than necessary to resolve the immediate case before it. ${ }^{25}$ Departures from precedent are supposed to be rare. ${ }^{26}$

$21 \quad$ Kenneth D. Chestek, Of Metaphors and Magic Wands, 89 Miss. L. Rev. (forthcoming 2020). One could easily come up with many other examples of how the slow evolution of common, interpretive, or Constitutional law has led to poor results.

558 U.S. $310(2010)$

Santa Clara County v. Southern Pacific Railroad, 118 U.S. 394 (1886).

For an excellent and well-documented examination of the entire 200-year process through which corporations gained their "civil rights," see generally WINKLER, supra note 1.

See, e.g., Wash. State Grange v. Wash. State Republican Party, 552 U.S. 442, 450 (2008) ("courts should neither 'anticipate a question of constitutional law in advance of the necessity of deciding it' nor 'formulate a rule of constitutional law broader than is required by the precise facts to which it is to be applied.") (internal quotation marks omitted). But note that the majority in Citizens United arguably did not adhere to that principle. See Citizens United v. FEC, 558 U.S. 310, 405-406 (2010) (Stevens, J., concurring in part and dissenting in part) (citing PDK Labs. Inc. v. U.S. D.E.A., 362 F.3d 786, 799 (D.C. Cir. 2004)) ("II]f it is not necessary to decide more, it is necessary not to decide more.").

Arizona v. Rumsey, 467 U.S. 203, 212 (1984) ("Although adherence to precedent is not rigidly required in constitutional cases, any departure from the doctrine of stare decisis demands special justification.”). 
But at some point, a court should take a step back, re-observe the world, and notice that the chain of decisions has led to an untenable public policy outcome: alreadywealthy corporations and individuals can use their power to virtually silence the voices of individuals in the political marketplace.

\section{OODA as a tool for case analysis and strategy selection}

As noted above, OODA is scalable and iterative. It can serve not only as a tool to guide case development and strategy selection at the beginning of the case, but can help make subsequent decisions as the case moves forward.

Perhaps thinking about a client's case as a problem to be solved through the OODA loop process can help. Let's take an example:

Three years ago, the National Organization of Libertarian Librarians (NALL) purchased a building in downtown Osage, State of Absaroka, from the Osage chapter of the International Order of Weird People (IOWP). The IOWP had used the building as its lodge and in support of its social welfare objectives, and had therefore been classified as exempt from real estate taxes under the State of Absaroka's Real Estate Tax Exemption statute. NALL is currently using the building as its national office headquarters, in which it houses an extensive and unique collection of books, monographs, and historical records relating to libertarian thought in the United States. While NALL receives about $60 \%$ of its funding through a fee-for-service arrangement with the national Libertarian Party, it is an independent organization with its own board of directors and direct donations and fee-for-service arrangements to make up the remaining $40 \%$ of its budget.

A few months ago, one of the Osage County Commissioners, a Democrat, inquired as to whether NALL was paying real estate taxes on its new headquarters building. A quick review of the tax records revealed that the tax status of the building had not been changed upon the sale, and that it was still listed as tax exempt. The commissioner then requested that the Absaroka County Assessor conduct an investigation to determine whether NALL's use of the building qualified for continued tax exemption under the state's tax exemption law.

You represent the County Assessor. How do you answer this question? ${ }^{27}$

Since this hypothetical is set in a fictional jurisdiction, please assume that the legal research and the law set forth below is accurate and complete. 


\section{A. Issue identification and selection}

The first step in the OODA process is to Observe: what is your problem?

The simple answer might be, "Does the NALL headquarters building satisfy the statutory requirement to be exempt real estate taxation?" That seems like a perfectly reasonable research problem. ${ }^{28}$ But remember Capt. Sullenberger, who observed that he was not only flying without working engines, but also that he was too far away from any airport to be able to reach it given his rate of descent. Taking that lesson to heart, perhaps the better place to start would be to ask, how many problems do you have?

Stepping back to that broader inquiry, you might identify at least the following problems:

1. Is there an administrative process available to raise and resolve this issue, or must there be a lawsuit?

2. Does the currrent use of the property meet the standards of the State of Absaroka Real Estate Exemption Law?

3. The building's use changed three years ago and was not questioned at the time; can it be challenged now? And if so, can the tax status be changed retroactively to three years ago?

4. Can a single member of the Board of Commissioners, a member of a political party that might have his own reasons to oppose an organization supporting a different political party, use his office to make life difficult for that opposing party?

The second question is the one that presented itself immediately. But the other three questions turn out to be critically important too. The Democratic commissioner who asked that second question might not have thought about the other three questions, but the lawyer representing the County Assessor needs to think about and propose answers to all four questions.

$28 \quad$ It also might be called a "premature diagnosis." See, e.g., Becky Jacobs, Cultivating Purposeful Curiosity in a Clinical Setting: Extrapolating from Case to Social Justice, 21 Clinical L. Rev. 371, 375 (2015) (and sources cited therein). 
The next step in the process is to identify in which order the questions should logically be addressed. Here you might ask: are there threshold or procedural questions that need to be answered before you can address the substantive issue? In our hypothetical, it appears that there are. For example, the standing question (number 4 on the list above) might need to be resolved first, since if there is nobody around who has the right to raise the issue, the merits will never be reached.

In selecting the order in which to address the four problems, it might help to back up one level of generalization and think about the dispute resolution process. The journalist's list of standard questions to ask might be useful here: who, what, where, when, and how ${ }^{29}$ Asking those questions in this context might go something like this: (1) Who is allowed to raise the issue? (2) Who or what body will resolve the issue, and where will that decision-making process occur? (3) When is the correct time to resolve the issue? That is, has the issue been raised too early (e.g. no case or controversy yet) or too late (e.g. statute of limitations has expired)? And (4) how should the issue be resolved on the merits? Looking at that structure, the four questions we identified previously could be logically addressed in the following order:

1. Who gets to ask this kind of a question? Can a single member of the Board of Commissioners, a member of a political party that might have his own reasons to oppose an organization supporting a different political party, use his office to make life difficult for that opposing party?

2. What body gets to answer this kind of a question? Is there an administrative process available to raise and resolve it, or must there be a lawsuit?

3. When can this kind of a question be asked? The building's use changed three years ago and was not questioned at the time; can it be challenged now? And if so, can the tax status be changed retroactively to three years ago? 
4. How is this question likely to be resolved on the merits? That is, does the currrent use of the property meet the standards of the Absaroka Real Estate Tax Exemption Law ${ }^{30}$

\section{B. Resolving the issues}

Having completed a thorough Observation process, we have now identified four problems to be solved, and a logical sequence in which to address them. Each one of them will require its own iteration of OODA to resolve.

\section{Loop 1: Solve the first problem}

Let's take the first problem identified above: Can a single member of the Board of Commissioners, a member of a political party that might have his own reasons to oppose an organization supporting a different political party, use his office to make life difficult for that opposing party? Having Observed that problem, the lawyer now moves on to Orienting herself in the issue. This involves both critical thinking about what legal or moral issues might be implicated by the problem, and then conducting research into how those issues might be resolved. She might ask herself:

- Who has the authority to direct the County Assessor to undertake this investigation? Since under Absaroka state statute the County Assessor is an independently elected officer of the county, does he have to do what the County Commissioners tell him to do?

- If the assessor is subject to the direction of the County Commissioners, how do the Commissioners exercise that authority? Can a single member of the three-member board exercise that authority, or must it be done by a vote of the full board at a public meeting?

- If a single Commissioner cannot act on behalf of the Board in directing the Assessor to conduct this investigation, does that Commissioner, acting in his private capacity as a taxpayer of Osage County, have a

Prof. Linda Morton has proposed a similar set of questions to be asked at the problemidentification phase: "What is the problem? Is there more than one? Is it part of a larger problem? If so, what should be addressed first? What interests are involved? Whose are they? Client's? Lawyer's? Opposing Party's? Society's? Is the problem big or small? Long-term or Short-term? Who are the stakeholders? What/whom does it harm? What are our objectives? Whose/what help do we need to identify the problem?" Morton, supra n. 3, at 382. 
right to demand the investigation?

- Alternatively, if the County Assessor does not conduct an investigation, would a private taxpayer of the County have a right to appeal the classification of the NALL headquarters building as exempt, on the theory that his taxes are marginally higher because NALL is improperly excused from paying real estate tax? That is, does a private citizen have standing to appeal NALL's tax status?

- If a private citizen could file a challenge to NALL's tax status, does the Democratic County Commissioner also have that right, or might he be disqualified on a theory that he is using his office to harass a potential political adversary?

The next step in Orienting is to do the research needed to solve all of the subproblems (a/k/a sub-issues) identified above. It may turn out that some of them are relatively easy to resolve by simple reference to a statutory provision, or a key case that is on point, is mandatory authority and remains good law. Other sub-issues may require more detailed analysis using an IRAC-type analysis.

Once the research is complete, the Orient phase is complete and the author moves to the Decide phase. Applying the law to the facts presented, what answer presents itself? This may vary depending on whether you are doing objective/predictive writing or advocacy, as we will discuss below. The author (the legal advisor to the County Assessor) then Acts by writing a memo or a brief conveying to the client the conclusion drawn in the Decide phase.

\section{Loops 2 through 4}

The decision the author reaches at the end of the first OODA loop may change the universe that the author is dealing with. Suppose, for example, the author concludes at the end of Loop 1 that the County Assessor has independent judgment and cannot be instructed by the County Commissioners to perform his duties in a particular manner, but that private citizens likely have standing to raise the issue of the propriety of any determination that a particular property does not meet the requirements for tax exemption. That conclusion likely changes the way the author views and resolves Issue 2: Is there an administrative process available to raise and resolve the exemption question, or must there be a lawsuit? And if a lawsuit, what is the proper forum and venue for that lawsuit? 
The author now engages in the Orient, Decide, and Act phases of resolving Issue 2. Upon resolving issue 2, the author then looks at Issue 3 to analyze whether the resolutions of issues 1 and 2 change the universe in a material way for that issue. And on through Issue 4.

\section{Handling contingent or alternative resolutions}

Attorneys rarely have the luxury of absolute certainty. ${ }^{31}$ Despite their most thorough research and careful analysis, they can never be certain that any court or other tribunal, when faced with the same facts and legal precedents, will reach the same conclusion they did. Thus, the attorney trying to give sound legal advice based upon predicting how some future court would likely resolve a particular dispute is well advised to couch their conclusions in terms of probabilities, not certainties. And, more importantly, to play out several alternative resolutions "just in case."

The OODA process can accommodate this need. Just as the fighter pilot needs a backup plan (deploying flares) in case his first plan (deploying chaff) fails, the legal advocate must plan for alternative resolutions of a problem in case the first resolution does not happen. The only difference is that the lawyer may not know the outcome of one iteration of the loop. The fighter pilot can Observe that the chaff did not distract the pursuing missile, so his decision to deploy flares is made with more complete knowledge of the situation he faces; the attorney rarely has that luxury. Instead, the lawyer must pre-plan her options: "if theory A fails, then theory B might work instead."

Note that the OODA process is fundamentally different from "decision tree" analysis that has become popular in practitioner literature.$^{32}$ Decision tree analysis is a useful tool for determining the potential value of any case for settlement

At least, attorneys who profess certainty (and act upon that belief) are more prone to malpractice suits than attorney who embrace uncertainty. Trees in Developing Litigation Strategy, DCBA Brief, November 2007, at 16; R. Stephen McNeill, Applying Decision Tree Analysis to Expedite Preference Settlements, Am. Bankr. Inst. J., Dec. 2015, at 32; Marc B. Victor, Resolving a Dispute by Getting a Neutral to Provide Probability Assessments, Alternatives to High Cost Litig., March 2013, at 36; Marc B. Victor, Decision Tree Analysis: a Means of Reducing Litigation Uncertainty and Facilitating Good Settlements, 31 Ga. St. U. L. Rev. 715 (2015). 
purposes. It can help you determine the probable value of any strategy you and the client may choose; it does not help you develop those strategies.

\section{How the lens of advocacy affects the resolution}

Thus far, I have been dealing with OODA in the generalized context of "resolving legal problems." But of course there is a difference in practice depending on whether the author is doing predictive (a/k/a "objective") analysis, or she is advocating for a result. In the predictive context, the author is not seeking a particular result; she is trying to find the "right" answer regardless of whether that results favors or harms her client's preferred outcome (or whether she has a client at all). In the latter context, of course, the author is trying to persuade a tribunal to reach a specific result favorable to her client.

This makes a difference at every stage of the OODA loop.

\section{Objective/predictive analysis}

Let's return to the example of the tax exemption case for the NALL headquarters building in Osage County. Suppose on Loop 1, the lawyer representing the County Assessor concludes that a taxpayer does have standing to challenge the tax exemption granted to another taxpayer, if certain conditions are met (for example, that the plaintiff is a real estate taxpayer in Osage County).

On Loop 2, the lawyer concludes that a taxing authority (such as the County Commissioners) could have challenged the designation of the property as exempt each year upon publication by the Assessor of that year's tax roll by filing an appeal of that designation. However, since no taxing body filed such an appeal, the time for appeal has now passed and any further challenge would be untimely, and any derivative appeal for previous years that a private taxpayer might bring would likewise be untimely. Prospectively, the proper procedure would be for a taxing body to file an appeal of the assessment upon publication of next year's tax roll, or for a taxpayer to file an action in mandamus in the state trial court, seeking an order directing the assessor to properly apply the state tax exemption laws by placing the property on the tax roll where it legally belongs. There is a possible defense that the action sought (placing the NALL property on the list of taxable properties) is a discretionary action and therefore cannot be ordered through mandamus, but there is an equally strong argument that the assessor must apply the law fairly and that his actions are reviewable in an action of mandamus. 
On Loop 3, the lawyer concludes that such an action can be prospective only, because the previous three years of exemption could only have been reviewed through an appeal by a taxing body to that year's assessment roll, and cannot be challenged in a forward-looking action in mandamus.

The resolution of Loop 4 cannot be completed at this time in the absence of notice and a hearing on the current use of the property to determine whether it meets the definitions in the Absaroka Real Estate Tax Exemption law.

The lawyer representing the County Assessor in this case, hopefully, is doing objective legal analysis, trying to get the "right" answer regardless of what the County Assessor might prefer to do. But notice how the OODA process might differ for the attorney for the private citizen who thinks NALL should be paying taxes on that building.

\section{Persuasive analysis}

Let's look at the same OODA process from the point of view of the lawyer for the taxpayer/prospective plaintiff:

Loop 1: just like the lawyer for the County Assessor, the lawyer for the taxpayer concludes that a taxpayer does have standing to challenge the tax exemption granted to another property owner. The OODA process revealed a potential pitfall, so the lawyer double-checks to be sure that his client does pay real estate taxes in Osage County. Finding that he does, the resolution of Issue 1 favors his client, so he can move on to Issue 2.

Loop 2: the lawyer for the taxpayer also concludes that the law requires taxing bodies to file appeals of assessments, including a determination of taxexempt status, within a certain time period after the annual assessment rolls are published, and that failure to appeal constitutes a waiver of the right to later contest that status. Further, the lawyer also concludes that a prospective appeal by a taxing body could be made for future tax years, and that the taxpayer could file an action in mandamus should the County Assessor not, on his own, list the property as taxable for the next tax year.

These decisions have several consequences for the taxpayer's attorney. At a minimum, they influence the Act phase: he should advise his client to wait for the publication of next year's tax rolls. If the NALL property remains listed as exempt for the next tax year, he should advise his client to (a) petition the taxing bodies to 
appeal the tax-exempt designation, and (b) if they do not, his client should consider filing an action in mandamus to force the County Assessor to list the property as taxable.

But those actions still let NALL off the hook for three years' worth of property taxes that his client believes NALL should have paid. In other words, the Decide phase of the Loop 2 OODA process came up with an answer that did not favor the client's interest.

The OODA process accounts for such things. Recall that, at the end of each OODA iteration, the decision-maker needs to make a new Observation: did the Act (or in this case, the possible action) solve the problem? And even if it solved the immediate problem, did it create a new problem? In this case, from the point of view of the taxpayer's attorney, the resolution of Loop 2 created a new problem: it has revealed that the County Commissioners (as well as potentially other taxing entities such as the school district or local government) may have been negligent in failing to file an appeal in the previous years. This opens up new research questions about whether a taxpayer might have a legal remedy against the commissioners (as opposed to a political one, such as voting them out of office at the next election). The OODA process resulting from that Observation may lead to a new Act: a decision to sue the County Commissioners for damages for failing to previously appeal the tax exempt status of the NALL headquarters building. ${ }^{33}$

Loop 3 also may proceed differently from the point of view of the taxpayer's attorney. The lawyer for the County Assessor concluded that the mandamus action could be prospective only, because the previous three years of exemption could only have been reviewed through an appeal by a taxing body to that year's assessment roll, and could not be challenged in a forward-looking action in mandamus. If the lawyer for the taxpayer comes out of Loop 2 with a different (or supplemental) Act (suing the County Commissioners for damages for negligently failing to appeal prior assessments of the NALL headquarters building), the Observation entering Loop 3 will look different from the perspective of the attorney for the County Assessor.

33 And OODA would continue from there. The Act to sue the commissioners could result in a new Observation: public officials are often immune from suit for their discretionary acts. Another OODA iteration would then follow to decide whether a suit for damages would be precluded by governmental immunity. 
Starting from a different Observation will greatly influence the progression of the remaining OODA steps, potentially leading to a very different Decision and Action.

The differences between the OODA processes for the counsel for the County Assessor and counsel for the taxpayer is summarized in this chart:

\begin{tabular}{|l|l|l|}
\hline & \multicolumn{1}{|c|}{$\begin{array}{c}\text { OODA Process for County } \\
\text { Assessor (objective analysis) }\end{array}$} & \multicolumn{1}{|c|}{$\begin{array}{c}\text { OODA Process for Taxpayer } \\
\text { (advocacy focus) }\end{array}$} \\
\hline $\begin{array}{l}\text { Loop 1 } \\
\text { standing) }\end{array}$ & $\begin{array}{l}\text { Assessor is independently } \\
\text { elected official and cannot be } \\
\text { directed by Commissioners to } \\
\text { take any action. Commissioners } \\
\text { can appeal prospective } \\
\text { assessments however, as can } \\
\text { other taxpayers. }\end{array}$ & $\begin{array}{l}\text { Taxpayer has standing to } \\
\text { challenge exempt status. } \\
\text { Lawyer's client is a taxpayer, so } \\
\text { proceed to Loop 2. }\end{array}$ \\
\hline $\begin{array}{l}\text { Loop 2 forum) } \\
\text { Past years cannot be reviewed. } \\
\text { Future years can be challenged } \\
\text { through administrative appeal. } \\
\text { Other taxpayers may have the } \\
\text { right to seek court order in } \\
\text { mandamus. }\end{array}$ & $\begin{array}{l}\text { Current law suggests that past } \\
\text { the fault of the commissioners for } \\
\text { not filing timely appeals in } \\
\text { previous years. What are } \\
\text { possible remedies for this } \\
\text { failure? (a) Political remedy (vote } \\
\text { commissioners out of office); (b) } \\
\text { Legal remedy (action for } \\
\text { damages for neglect of duty to } \\
\text { properly review tax rolls); (c) } \\
\text { Mandamus action against } \\
\text { Assessor to prospectively change } \\
\text { assessment. }\end{array}$ \\
& &
\end{tabular}




\begin{tabular}{|l|l|l|}
\hline $\begin{array}{l}\text { Loop 3 } \\
\text { (timing) }\end{array}$ & $\begin{array}{l}\text { Past three years cannot be } \\
\text { reviewed. Appeals and } \\
\text { mandamus are prospective } \\
\text { remedies only. }\end{array}$ & $\begin{array}{l}\text { (a) Taxpayer will handle, no } \\
\text { legal intervention needed } \\
\text { (b) Is decision to appeal or not a } \\
\text { discretionary action that can be } \\
\text { tested in an action for damages? } \\
\text { Who would pay damages if action } \\
\text { is successful (i.e. commissioners } \\
\text { or insurance)? } \\
\text { (c) Prerequisites for filing } \\
\text { prospective mandamus action? } \\
\text { Joinder of NALL in order to } \\
\text { gather information needed to } \\
\text { resolve Loop 4? }\end{array}$ \\
\hline $\begin{array}{l}\text { Loop 4 } \\
\text { (merits) }\end{array}$ & $\begin{array}{l}\text { Unable to resolve in the absence } \\
\text { of evidence to be gathered } \\
\text { during formal appeal process. }\end{array}$ & $\begin{array}{l}\text { (a) Campaign to vote } \\
\text { commissioners out of office will } \\
\text { be resolved at next election. } \\
\text { (b) Unable to resolve in the } \\
\text { absence of evidence regarding } \\
\text { possible insurance coverage } \\
\text { available to satisfy judgment. } \\
\text { (c) Unable to resolve in the } \\
\text { absence of evidence regarding } \\
\text { use of the property to be } \\
\text { gathered during mandamus } \\
\text { action. }\end{array}$ \\
\hline
\end{tabular}

In the case of the County Assessor, the attorney asked only the question "what is the correct answer?" The attorney for the taxpayer asked a different question: "how can my client achieve what he perceives to be justice?" While both attorneys reached the same conclusion at Loop 1, by asking the different questions on Loop 2 the OODA processes began to quickly diverge, and the possible range of results for the taxpayer became far more complex.

Note, too, that the need for alternative decisions (discussed in section II-D above) come into play here too. The advocate may spin out one series of OODA 
processes leading to the client's preferred outcome. But the good advocate will recognize that the decisionmaker (judge, jury or some administrative tribunal) might disagree with her rationale, find the other side's rationale more persuasive, or even come up with an entirely new rationale. The advocate needs to prepare a contingency plan to deal with that, to the extent possible, by proposing alternative resolutions based on alternative Decisions in any OODA loop.

\section{OODA as a large-scale organization paradigm for legal writing}

We don't yet have a good paradigm for large-scale organization of a complex bit of legal writing (either an analytical memorandum or a persuasive brief to a decisionmaker). Most textbooks simply advise the writer to "organize the issues in a logical fashion" or to "deal with threshold issues first." ${ }^{34}$ Prof. Linda Edwards goes a little farther, suggesting that there are at least four different choices a writer can make: "(1) ordering by strength on the law, (2) ordering by strength on the equities, (3) ordering by the reader's priorities, and (4) ordering by familiarity." ${ }^{35}$ But she does not suggest how a writer should choose among those options.

Perhaps a good OODA analysis can help the legal writer decide how to present the issues. The same who/what/when/where/why/how process described above $^{36}$ might also suggest the most logical sequence in which to present the issues to your reader.

\section{The ethics of OODA in legal advocacy}

As noted above, ${ }^{37}$ OODA has a dark side. While it can help somebody-anybody from a pilot in a life-and-death situation to a legal writer-reach a good decision through an orderly process, the knowledge that your enemy is also using OODA can be used as a tool to disrupt the enemy's decision-making process.

John C. Dernbach et al., A Practical Guide to Legal Writing \& Legal Method (Fifth Ed. 2013) p. 158; accord CHARLEs R. CALleros, LEgAl METHOD AND WRITING (Fifth Ed. 2006) p. 217; RichaRd K. NEUMANN, JR., LEgAL REASONING AND LEGAL WRITING: STRUCTURE, Strategy, AND Style (Sixth Ed. 2009) p. 118; LAurEl OATES ET AL., JUSt Briefs (2d Ed. 2008) at 25.

35 Linda H. Edwards, Legal Writing: Process, ANAlysis, ANd Organization (Fifth Ed. 2010) p. 321.

$36 \quad$ See text accompanying n. 18, supra.

$37 \quad$ See Part I-C, supra.

$-25-$ 
And while that may be life-saving for the fighter pilot in a time of war, the rules of engagement in legal problem-solving ${ }^{38}$ are a little different. ${ }^{39}$

The previous discussion established how two advocates, approaching the same problem from different perspectives (the attorney objectively representing the County Assessor and the attorney representing an allegedly aggrieved taxpayer), can use the OODA process to legitimately reach differing conclusions. But in that discussion, each attorney independently used OODA as the basis for his or her own decision. Would it be fair, or ethical, for either attorney to attempt to disrupt the other's OODA process in order to achieve a better result for his or her client?

While some advocates tend to analyze litigation as a form of warfare, ${ }^{40}$ the Model Rules of Professional Conduct put constraints on that sort of behavior. In particular, Model Rule 3.3 seems to clearly prohibit an advocate from deliberately trying to disrupt the OODA process of the judge, or even of opposing counsel:

(a) A lawyer shall not knowingly:

(1) make a false statement of fact or law to a tribunal or fail to correct a false statement of material fact or law previously made to the tribunal by

This Article has focused on using OODA in a litigation context to resolve disputes between parties. However, OODA could also be successfully deployed by a transactional lawyer in just about any context. In particular, the requirement to re-Observe the changed conditions after each Action is implemented can be a valuable exercise for the forward-thinking transactional attorney trying to anticipate what might go wrong in the future, so that she can draft a contract or other transactional document to avoid that future problem.

See M. Margaret McKeown, A Judge Comments, Litigation, Winter 2013, at 25, 27 ("Sun Tzu's advice that 'all warfare is based on deception,' designed to win at all costs, is anathema to the courts. Unfortunately, discovery disputes are a fertile battleground. Any trial strategy must account for the consequences of bloody discovery battles and their long-term implications. Deceit, hiding the ball, and unnecessary delay are tantamount to shooting yourself in the foot.”).

William N. Shepherd and Thomas D. Smith, Sun Tzu and the Art of Trial, Litigation, Winter 2013, at 24("The first trial manual was written thousands of years ago by a military stragegist responsible for training his king's troops during the Warring States period in sixt century B.C. China. Although Sun Tzu wrote The Art of War as a manual for training warriors, its lessons and principles apply equally to preparing for the conflict of trial in the adversary system."). Indeed, it is common for law firms to set up "war rooms" to manage major litigation. Walter G. Sutton, The War Room: A Case Study, Practical Lawyer, June 1992 , at 15 . 
the lawyer;

(2) fail to disclose to the tribunal legal authority in the controlling jurisdiction known to the lawyer to be directly adverse to the position of the client and not disclosed by opposing counsel; or

(3) offer evidence that the lawyer knows to be false. If a lawyer, the lawyer's client, or a witness called by the lawyer, has offered material evidence and the lawyer comes to know of its falsity, the lawyer shall take reasonable remedial measures, including, if necessary, disclosure to the tribunal. A lawyer may refuse to offer evidence, other than the testimony of a defendant in a criminal matter, that the lawyer reasonably believes is false. ${ }^{41}$

An ethical lawyer thus cannot "make a false statement of fact or law, ... fail to correct [previous false statements], fail to disclose ... legal authority in the controlling jurisdiction known to the lawyer to be directly adverse to the position of the client ..., [or] offer evidence that the lawyer knows to be false," in order to disrupt the OODA process of either a tribunal or opposing counsel.

The application of Model Rule 3.1 is less clear:

A lawyer shall not bring or defend a proceeding, or assert or controvert an issue therein, unless there is a basis in law and fact for doing so that is not frivolous, which includes a good faith argument for an extension, modification or reversal of existing law. ${ }^{42}$

Suppose Plaintiff's lawyer believes his client has a good cause of action against a Defendant on legal theory A. There is also a remote, but still non-zero chance that Plaintiff could also prevail against Defendant on legal theory B. The legal question raised by Model Rule 3.1 would be whether or not legal theory B is "frivolous".

Suppose further that Plaintiff's lawyer concludes legal theory B is not frivolous, and he therefore files a two-count complaint against Defendant alleging both theories A and B. Suppose further that he hopes (secretly or even openly) that

$41 \quad$ ABA Model Rule of Professional Conduct 3.3.

42 ABA Model Rule or Professional Conduct 3.1. 
Defendant will spend a great deal of time and effort defending against theory B. This is a form of disrupting the opponent's OODA process (e.g. by distracting the Defendant), especially if the Plaintiff expects to drop theory B prior to trial in order to not distract the trier of fact from the sounder theory A. According to the rules of engagement for warfare, for which OODA was designed, the multi-count complaint is perfectly fine. In the world of legal ethics, however, the issue is much more complex, and the resolution much less certain.

Another temptation for deploying OODA as an attack on the opposing side is during discovery. So-called "hardball discovery tactics," especially in high-stakes litigation, can degenerate into efforts to distract and disrupt the other side's OODA process. ${ }^{43}$ But it doesn't necessarily need to go that far. There is a difference between playing within the rules, and deliberately obfuscating, delaying, or making litigation as expensive as possible for the other side. ${ }^{44}$

Note also that just because the Model Rules prohibit unethical behavior, that does not mean a lawyer might not encounter unethical conduct by an opposing party. Being aware of the OODA process, and most importantly how it can be weaponized, may help a lawyer get back on track when faced with misleading or distracting inputs from the other side.

\section{Concluding thoughts}

I never expected to be writing an article whose premise is grounded in a military strategy. But I take wisdom where I find it. OODA is a simple idea that is actually brilliant when applied to any form of problem-solving. It helps the problemsolver think about the process of solving the problem, and when done consciously and patiently, can help a problem solver avoid common pitfalls.

In a legal context, OODA forces the lawyer to think critically and creatively. It also helps a lawyer to focus on counteranalysis. By forcing oneself to Observe the result of one's Decision before moving on to the next iteration, hopefully the lawyer

${ }_{43}$ See, e.g., Steve Weinberg, Hardball Discovery, ABA Journal, Nov. 1995, at 66.

$44 \quad$ Stephanie Goldberg, Playing Hardball, ABA Journal, July 1987, at 48 ("'Hardball is playing with a baseball, not a softball; it's faster and harder hitting and implies a high level of professionalism and the major leagues.' But, says [Monroe] Freedman, it doesn't mean spitball or sleazeball. 'It's a game where winning within the bounds of the rules is the most important thing."”). 
will be more attuned to potential flaws in the decision-making process, or unintended consequences flowing from the Decision, and address them on the next loop. 